\title{
SPATIAL ARRANGEMENT ANALYSIS OF WHEAT AND RYE GENOMES IN TRITICALE INTERPHASE NUCLEI BY GAMMA-RADIATION INDUCED CHROMOSOMAL IN TERCHANGES
}

\author{
M. C. CERMENO AND J. R. LACADENA \\ Departamento de Genética, Facultad de Biologra, Universidad Complutense, Madrid, \\ Spain
}

Received 10.i.83

\section{SUMMARY}

\begin{abstract}
Gamma-radiation chromosomal interchanges are induced in the "Cachirulo" hexaploid triticale to analyze the spatial arrangement of wheat and rye genomes in the somatic nuclei. The frequencies of wheat-wheat, wheat-rye and rye-rye dicentric chromosomes observed fit a random distribution. While the centromeres of different genomes may be separate in space, the arms of the wheat and rye chromosomes are, in general, randomly disposed within the nucleus.
\end{abstract}

\section{INTRODUCTION}

Spatial arrangement of chromosomal sets which constitute the chromosome complement of an organism has been analyzed in allopolyploid species (common wheat, Feldman and Avivi, 1973a, b; Avivi et al., 1982), in interspecific hybrids (Hordeum $\times$ Secale, Finch et al., 1981) and in diploid species (human, Coll et al., 1980; barley, Bennett, 1982). In all the cases, a tendency of genomes to occupy different areas of the somatic nuclei seemed to be inferred.

On the other hand, evidence for a specific chromosomal arrangement in the interphase nuclei has been inferred from the analysis of both spontaneous (Jancey and Walden, 1972; Jancey, 1975; Walden and Jancey, 1976) and induced translocations (Sax, 1940; Evans and Bigger, 1961; Kumar and Natarajan, 1966; Werry et al., 1977; Kaina et al., 1979).

In the present paper gamma-radiation chromosomal interchanges are induced in triticale in order to analyze the spatial arrangement of wheat and rye genomes.

\section{MATERIAL AND METhODS}

Seeds of "Cachirulo" hexaploid triticale $(2 n=6 x=42$, genome constitution AABBRR) were used. Seeds were germinated on wetted filter paper in Petri dishes for $48 \mathrm{~h}$ at room temperature and subsequently exposed to a continuous gamma-rays source of ${ }^{60} \mathrm{Co}(0.0803 \mathrm{Mrad} / \mathrm{h})$ at 1 and $2 \mathrm{Krad}$ doses.

Root-tips were excised $20 \mathrm{~h}$ and $48 \mathrm{~h}$ after irradiation and immersed in tap water at $4^{\circ} \mathrm{C}$ for $48 \mathrm{~h}$ in order to shorten the chromosomes. After that the root-tips were fixed in $1: 3$ acetic ethanol.

Cytological preparations were made by squashing in a drop of 45 per cent acetic acid. Metaphase plates were observed and photographed under phase contrast in order to identify clearly the number and position of 
centromeres. After that the same metaphase plates were analyzed by using the C-banding technique described by Giráldez et al., (1979). The Cbanding pattern of wheat chromosomes ( $\mathrm{A}$ and $\mathrm{B}$ genomes) is quite different from that of rye chromosomes ( $\mathrm{R}$ genome). C-bands are preferentially telomeric in rye chromosomes and pericentromeric and scattered throughout the chromatids in wheat chromosomes (fig. 1). For this reason it is possible to distinguish between the three different types of chromosomal interchanges, namely, wheat-wheat $(\mathrm{W}-\mathrm{W})$, wheat-rye $(\mathrm{W}-\mathrm{R})$ and rye-rye (R-R),

For the sake of accuracy, asymmetrical interchanges-that is to say, dicentric chromosomes-were only taken into consideration since the Cbanding patterns of wheat and rye chromosomes can give rise to monocentric interchanges which are difficult to identify.

As indicated above, the number and position of centromeres were determined by phase contrast, which facilitates the detection of wheat dicentrics in which the centromeres were very close.

\section{Results}

The three different types of dicentric chromosomes (wheat-wheat, wheat-rye and rye-rye) produced by asymmetrical interchanges are shown in figs. 2 and 3 . Table 1 gives the frequencies of dicentrics and chromosomal

TABLE 1

Frequencies of dicentric chromosomes induced by gamma-radiation in "Cachirulo" hexaploid triticale at different doses and at different intervals after exposure to radiation. Frequencies of chromosomal breakages are also indicated

\begin{tabular}{|c|c|c|c|c|c|c|c|}
\hline \multirow{2}{*}{$\begin{array}{l}\text { Time of } \\
\text { observation } \\
\text { (hours) }\end{array}$} & \multirow[b]{2}{*}{$\begin{array}{c}\text { Dose } \\
\text { (Krad) }\end{array}$} & \multicolumn{3}{|c|}{ Dicentric chromosomes } & \multicolumn{2}{|c|}{$\begin{array}{l}\text { Total No. of } \\
\text { chromosomal } \\
\text { breakages }\end{array}$} & \multirow[b]{2}{*}{$\begin{array}{l}\text { No. of } \\
\text { cells }\end{array}$} \\
\hline & & $\begin{array}{l}\text { Wheat- } \\
\text { Wheat }\end{array}$ & $\begin{array}{c}\text { Wheat- } \\
\text { Rye }\end{array}$ & Rye-Rye & Wheat & Rye & \\
\hline 20 & $\begin{array}{l}1 \\
2\end{array}$ & $\begin{array}{l}39 \\
53\end{array}$ & $\begin{array}{l}31 \\
45\end{array}$ & $\begin{array}{r}9 \\
14\end{array}$ & $\begin{array}{l}109 \\
151\end{array}$ & $\begin{array}{l}49 \\
73\end{array}$ & $\begin{array}{l}48 \\
36\end{array}$ \\
\hline 48 & 1 & 29 & 27 & 9 & 85 & 45 & 66 \\
\hline Total & & 121 & 103 & 32 & 345 & 167 & 150 \\
\hline
\end{tabular}

breakages induced at different doses and times of observation. There were no significant differences between effects of $1 \mathrm{Krad}$ and $2 \mathrm{Krad}$ doses observed $20 \mathrm{~h}$ after the exposure to radiation, either for the types of dicentric chromosomes produced $\left(\chi^{2}=0.098\right.$, d.f. $\left.=2,0.95<p<0.99\right)$ or the chromosomes involved in such interchanges $\left(\chi^{2}=0 \cdot 106\right.$, d.f. $=1,0 \cdot 90<$ $p<0.95)$.

Likewise, no significant differences were found on comparing the effects of radiation at different times after the exposure either for the types of dicentric chromosomes $\left(\chi^{2}=0.293\right.$, d.f. $\left.=2,0.80<p<0.90\right)$ or for types of chromosomes involved $\left(\chi^{2}=0.316\right.$, d.f. $\left.=1,0.95<p<0.98\right)$. Since the 


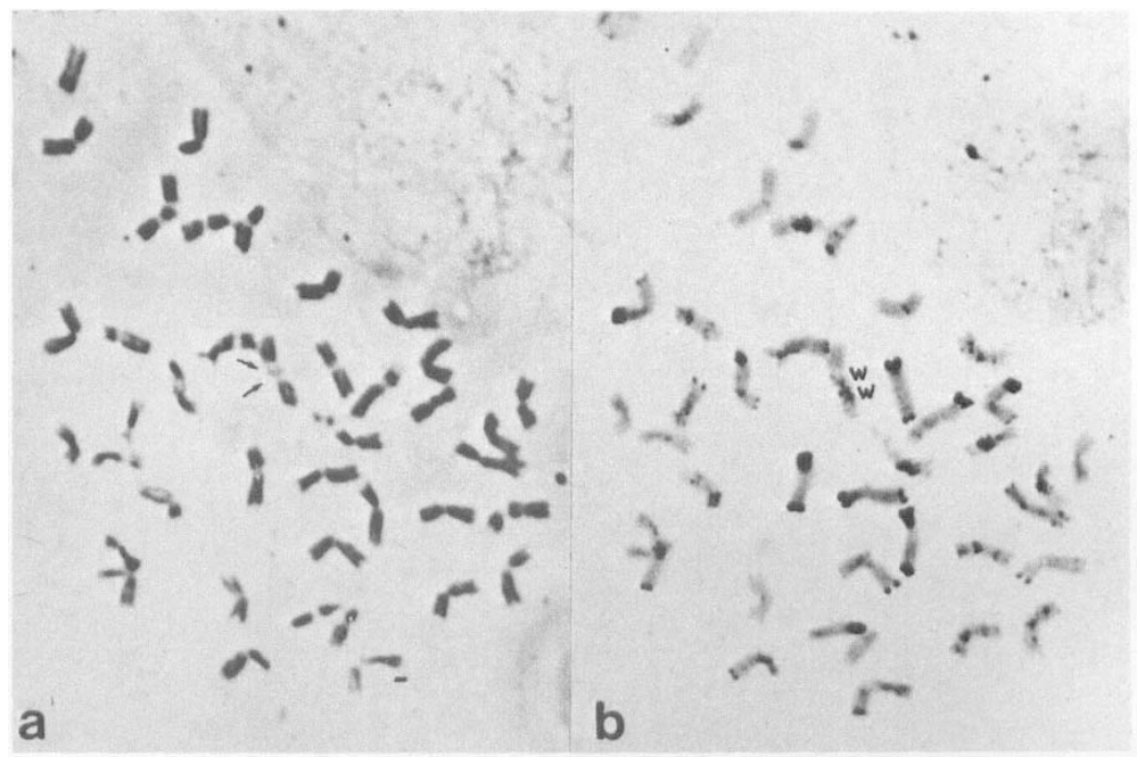

FIG. 2. Somatic metaphases of "Cachirulo" hexaploid triticale showing a wheat-wheat dicentric chromosome. a. Phase contrast. Arrows indicate the centromere positions. b. The same as (a) stained with C-banding technique.
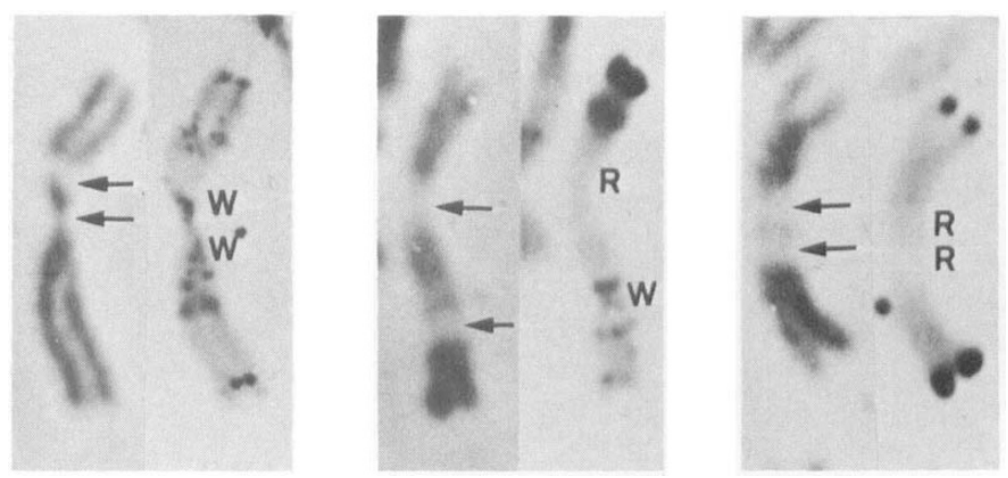

FIG. 3. Different types of dicentric chromosomes. Each interchange is shown by phase contrast (left) and C-banded (right). a. Wheat-wheat. b. Wheat-rye. c. Rye-Rye. Arrows indicate the centromere positions. 


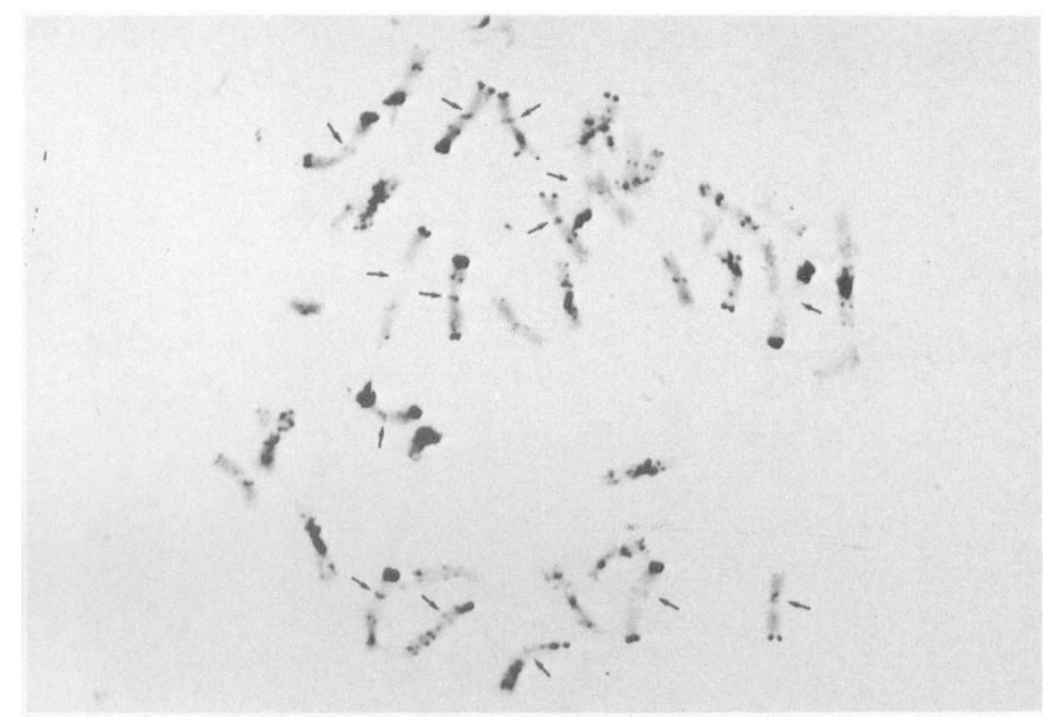

FIG. 1. C-banded somatic metaphase of "Cachirulo" hexaploid triticale. Rye chromosomes are indicated. 
two contingency chi-square tests were not significant the values were pooled.

The comparison of the observed total values with those expected on the basis of a random distribution is shown in table 2 . Significant differences were not found. The probability values for each class are indicated below:

Wheat-wheat interchange $=\left(\begin{array}{c}28 \\ 2\end{array}\right) /\left(\begin{array}{c}42 \\ 2\end{array}\right)=0.44$

Wheat-rye interchange $=28 \times 14 /\left(\begin{array}{c}42 \\ 2\end{array}\right)=0.45$

Rye-rye interchange $=\left(\begin{array}{c}14 \\ 2\end{array}\right) /\left(\begin{array}{c}42 \\ 2\end{array}\right)=0 \cdot 11$

Wheat chromosome breakage $=28 / 42=0.67$

Rye chromosome breakage $=14 / 42=0 \cdot 33$.

TABLE 2

The distribution of dicentric chromosomes after irradiation

\begin{tabular}{lcccccc}
\hline & \multicolumn{3}{c}{ Dicentric chromosomes } & & \multicolumn{2}{c}{ Chromosomes involved } \\
\cline { 2 - 3 } \cline { 7 - 7 } & Wheat-wheat & Wheat-Rye & Rye-Rye & & Wheat & Rye \\
\hline Obs. & 121 & 103 & 32 & & 345 & 167 \\
Exp. & 112.4 & 116.5 & 27.1 & & & \\
\hline
\end{tabular}

$x^{2}=3 \cdot 14$, d.f. $=2,0 \cdot 20<p<0 \cdot 30$

\section{Discussion}

From the results obtained it can be deduced that an increase in the dose of radiation results in an increase in the total frequency of dicentric chromosomes without modifying the relative frequencies either of the type of interchange (W-W, W-R, R-R) or of chromosomal breakage in wheat and rye chromosomes (table 1). These results are in agreement with those obtained in rye inbred lines (Cermeño et al., unpublished).

On the other hand, observations at increasing intervals after the exposure to radiation ( 48 instead of 20 hours) show a decrease in the total frequencies of dicentric chromosomes but show no change either in relative frequencies of the types of interchanges (W-W, W-R, R-R) or of chromosomal breakage in the wheat and rye chromosomes. So, it seems that cellular selection against chromosomal interchanges produces homogeneous effects.

From table 2 it can be deduced that the three different types of dicentric chromosomes (W-W, W-R, R-R) are induced according to a random pattern. This fact seems to be contrary to the assumption that different genomes are, relatively, separated from one another in the somatic nuclei (Finch $e t$ al., 1981; Bennett, 1982; Avivi et al., 1982). If the genomes were separated within the nucleus the expectation would be that wheat-wheat and rye-rye dicentric chromosomes should appear more frequently than expected at random. 
However, a plausible explanation can be afforded assuming that the arrangement of chromosomes in the nucleus is determined by their centromeres. So, in the interphase nucleus the uncoiled chromosome arms hang from their respective centromeres which are arranged on a ring in the cell pole (Avivi and Feldman, 1980; Avivi et al., 1982). When interphase nuclei are irradiated the interchanges occur at random between uncoiled chromosome arms which are intermingled filling the nuclear space even though the centromeres display a specific pattern of arrangement (Bennett, 1982; Jódar et al., 1983).

In conclusion our results indicate that while the centromeres of different genomes may be spatially separated within the nucleus the arms of the chromosomes during early interphase (when the nuclei were irradiated to produce chromosome breakage) are disposed more or less at random.

Acknowledgments. This work has been partially supported by a grant of the Comision Asesora de Investigación Científica y Técnica of Spain.

\section{REFERENCES}

AVIVI, L. AND FELDMAN, M. 1980. Arrangement of chromosomes in the interphase nucleus of plants. Hum. Genet., 55, 281-295.

AVIVI, L., FELDMAN, M. AND BROWN, M. 1982. An ordered arrangement of chromosomes in the somatic nucleus of common wheat, Triticum aestivum L. II. Spatial relationships between chromosomes of different genomes. Chromosoma (Berl.), 86, 17-26.

BENNETT, M. D. 1982. Nucleotypic basis of the spatial ordering of chromosomes in eukaryotes and the implications of the order for genome evolution and phenotypic variation. In $G$. A. Dover, R. B. Flavell (eds.) Genome evolution. Academic Press, London, pp. 239-261.

COLL, M. D., CUADRAS, C. M. AND EGOZCUE, J. 1980. Distribution of human chromosomes on the metaphase plate. Symmetrical arrangement in human male cells. Genet. Res. Camb., 36, 219-234.

EVANS, H. J. AND BIGGER, T. R. L. 1961. Chromatid aberrations induced by gamma irradiation. II. Non randomness in the distribution of chromatid abberrations in relation to chromosome length in Vicia faba root-tips cells. Genetics, 46, 277-289.

FELDMAN, M. AND AVIVI, L. 1973a. Non-random arrangement of chromosomes in common wheat. In Chromosomes Today 4, 187-196.

FELDMAN, M. AND AVIVI, L. 1973b. The pattern of chromosomal arrangement in nuclei of common wheat and its genetic control. Proc. 4th Inter. Wheat Genet. Symp. Missouri Agr. Exp. Stn., Columbia, Mo., pp. 675-684.

FINCH, R. A., SMITH, J. B. AND BENNETT, M. D. 1981. Hordeum and Secale mitotic genomes lie apart in a hybrid. J. Cell Sci., 52, 391-403.

GIRALDEZ, R., CERMEÑO, M. C. AND ORELLANA, J. 1979. Comparison of C-banding pattern in the chromosomes of inbred lines and open pollinated varieties of rye. Z. Pflanzenzüchtg., 83, 40-48.

JANCEY, R. C. 1975. A new source of evidence for the polarized nucleus in maize. Can. $J$. Genet. Cytol., 17, 245-252.

JANCEY, R. C. AND WALDEN, D. B. 1972. Analysis of pattern in distribution of breakage points in the chromosomes of Zea mays L. and D. melanogaster Meigen. Can. J. Genet. Cytol., 14, 429-442.

JODAR, B., FERRER, E. AND LACADENA, J. R. 1983. On the ordered arrangement of chromosomes of the haploid set in radial metaphases of secondary meiocytes of grasshoppers, Euchorthippus pulvinatus gallicus. (submitted).

KAINA, B., RIEGER, R., MICHAELIS, A. AND SCHUBERT, I. 1979. Effects of chromosome repatterning in Vicia faba L. IV. Chromosome constitution and its bearing on the frequency and distribution of chromatid aberrations. Biol. Zentralbl., 98, 271-283.

KUMAR, S. AND NATARAJAN, A. T. 1966. Kinetics of two-break chromosome exchanges and the spatial arrangement of chromosome strands in interphase nucleus. Nature, 209 , 796-797. 
SAX, K. 1940. Analysis of X-ray induced chromosomal aberrations in Tradescantia. Genetics, $25,41-68$.

WALDEN, D. B. AND JANCEY, R. C. 1976. Reassociation patterns among segmental interchanges in maize. Heredity, 36, 293-304.

WERRY, P. A. T. J., STOFFELSEN, K., ENGELS, F. M., VAN DER LAAN, F. AND SPANJERS, A. W. 1977. The relative arrangement of chromosomes in mitotic interphase and metaphase in Haplopappus gracilis. Chromosoma (Berl.), 62, 93-101. 